\title{
Intoxicação experimental pelas favas de Stryphnodendron obovatum (Leg. Mimosoideae) em bovinos. 2. Achados anátomo e histopatológicos ${ }^{1}$
}

\author{
Marilene F. Brito ${ }^{2}$, Carlos H. Tokarnia ${ }^{3}$ e Paulo V. Peixoto ${ }^{4}$
}

\begin{abstract}
Brito M.F., Tokarnia C.H. \& Peixoto P.V. 2001. [Pathology of experimental poisoning by the pods of Stryphnodendron obovatum (Leg. Mimosoideae) in cattle] Intoxicação experimental pelas favas de Stryphnodendron obovatum (Leg. Mimosoideae) em bovinos. 2. Achados anátomo e histopatólogicos. Pesquisa Veterinária Brasileira 21(2):61-71. Projeto Sanidade Animal Embrapa/UFRRJ, Km 47, Seropédica, RJ 23851-970, Brazil. e-mail: marilene@ufrrj.br

With the objective to characterize the gross and histopathological changes of poisoning by the tree Stryphnodendron obovatum Benth., of the Leguminosae Mimosoideae family, its pods were given orally to 17 young bovines. Five of the animals died from the poisoning. One of them received one dose of $60 \mathrm{~g} / \mathrm{kg}$, and four animals repeated doses $(10 \mathrm{~g} / \mathrm{kg}$ for 8 days, $20 \mathrm{~g} /$ $\mathrm{kg}$ for 3 days, $30 \mathrm{~g} / \mathrm{kg}$ for 2 days, and $40 \mathrm{~g} / \mathrm{kg}$ also during 2 days). At post-mortem examination there was reddening and adherence of the mucosal papillae, breaking up of the epithelium and congestion of the propria, mainly in the rumen and with less intensity in the reticulum and omasum. In the abomasum, focal and diffuse congestion of the mucosa, large areas of erosion and ulceration were observed. In the small intestine there was congestion of the mucosa, and the Peyer's plaques were red and well defined. In the large intestine slight to moderate congestion was seen. The mesenteric lymph nodes were reddend on the cut surface. Histological examination showed in the epithelium, from the oral cavity on up to the omasum, areas of acanthosis, spongiosis, parakeratosis, hyperkeratosis, necrosis and hydropic-vacuolar degeneration, with formation of intraepithelial vesicles or pustules, sometimes containing acantholytic keratocytes, and splitting of the epithelial layer in these areas. In the entire digestive tract, focal congestion and hemorrhages were observed, more severely in the abomasum and small intestine.
\end{abstract}

INDEX TERMS: Poisonous plants, experimental plant poisoning, Stryphnodendron obovatum, cattle, pathology.

RESUMO.- Com o objetivo de caracterizar as alterações anátomo e histopatológicas da intoxicação experimental por Stryphnodendron obovatum Benth. (fam. Leg. Mimosoideae), as favas desta árvore foram administradas, por via oral, a 17 bovinos jovens. Destes, cinco morreram, sendo que apenas um deles

\footnotetext{
${ }^{1}$ Aceito para publicação em 20 de março de 2001.

Parte da Dissertação de Doutorado do primeiro autor, apresentada ao Curso de Doutorado em Sanidade Animal da Universidade Federal Rural do Rio de Janeiro (UFRRJ).

${ }^{2}$ Depto Epidemiologia e Saúde Pública, Setor de Anatomia Patológica, UFRRJ, Km 47, Seropédica, RJ 23851-970; e-mail: marilene@ufrrj.br

32Depto Nutrição e Pastagem, UFRRJ; e-mail: tokarnia@ufrrj.br

${ }^{4}$ Depto Nutrição e Pastagem, UFRRJ; e-mail: peixoto@ufrrj.br
}

recebeu $60 \mathrm{~g} / \mathrm{kg}$ das favas, em dose única, e quatro as receberam em doses repetidas $(10 \mathrm{~g} / \mathrm{kg}$ durante 8 dias, $20 \mathrm{~g} / \mathrm{kg}$ durante 3 dias, $30 \mathrm{~g} / \mathrm{kg}$ durante 2 dias e $40 \mathrm{~g} / \mathrm{kg}$ durante 2 dias). Macroscopicamente, as lesões se caracterizaram por avermelhamento e aderência das papilas, desprendimento do epitélio e congestão da própria, sobretudo no rúmen e com menor intensidade no retículo e no omaso. No abomaso havia congestão difusa ou focal e grandes áreas com erosões/ulcerações. No intestino delgado observaram-se congestão da mucosa e placas de Peyer muito vermelhas e bem delimitadas e no intestino grosso leve a moderada congestão. Os linfonodos mesentéricos apresentavam-se avermelhados, ao corte. Histologicamente verificaram-se, desde a cavidade oral até o omaso, áreas de acantose, espongiose, paraqueratose, hiperqueratose, necrose e degeneração hidrópico-vacuolar, 
com formação de vesículas ou pústulas intra-epiteliais, por vezes contendo queratinócitos acantolíticos, e desprendimento epitelial nestas áreas. Congestão e hemorragias focais foram observadas em todo trato digestivo, porém eram mais acentuadas no abomaso e no intestino delgado.

TERMOS DE INDEXAÇÃO: Plantas tóxicas, intoxicação experimental por plantas, Stryphnodendron obovatum, bovinos, patologia.

\section{INTRODUÇÃO}

O presente trabalho constitui a complementação do estudo clínico efetuado em bovinos intoxicados pelas favas de Stryphnodendron obovatum Benth. (Brito et al. 2001). Neste trabalho são abordados os aspectos macro e microscópicos desta intoxicação.

\section{MATERIAL E MÉTODOS}

O estudo foi realizado nas instalações do Projeto Sanidade Animal da Empresa Brasileira de Pesquisa Agropecuária, Convênio Embrapa/ Universidade Federal Rural do Rio de Janeiro (UFRRJ), Seropédica, RJ. O delineamento experimental completo consta no trabalho anteriormente publicado (Brito et al. 2001).

Os animais que morreram foram necropsiados imediatamente após a morte. Os fragmentos destinados ao estudo histopatológico foram fixados em formalina-PBS (fosfato salino tamponado) a $10 \% \mathrm{e}$ o sistema nervoso central foi fixado em formalina-PBS a $20 \%$. Foram coletados fragmentos de pele, mucosa oral, linfonodos superficiais e mesentéricos, traquéia, tireóide, pulmão, coração, fígado, baço, adrenal, rim, bexiga, esôfago, rúmen, retículo, omaso, abomaso, pâncreas, duodeno, jejuno, íleo, ceco, cólon, reto, cérebro e cerebelo. Essas amostras foram processadas pelos métodos usuais, incluídas em parafina, cortadas na espessura de $5 \mu \mathrm{m}$ e coradas pela técnica de hematoxilina-eosina (HE).

\section{RESULTADOS}

Dos 17 bovinos que receberam as favas, cinco morreram. Dos animais que receberam dose única, apenas o Bovino 840 (60g/ $\mathrm{kg}$ ) morreu. As demais mortes ocorreram nos bovinos que receberam doses repetidas $(10 \mathrm{~g} / \mathrm{kg}$ por 8 dias, Bov. $5210 ; 20 \mathrm{~g} /$ $\mathrm{kg}$ por 3 dias, Bov. 4919; 30g/kg por 2 dias, Bov. 802, e $40 \mathrm{~g} / \mathrm{kg}$ por 2 dias, Bov. 182).

\section{Achados de necropsia (Quadro 1)}

À necropsia observaram-se algumas úlceras bem demarcadas no terço médio do esôfago (Fig. 1). Foi possível identi- ficar fragmentos das favas no conteúdo desde o rúmen até o intestino. $O$ conteúdo do rúmen, retículo, omaso e abomaso estava levemente ressecado ou pastoso, ou com parte pastosa e parte líquida ou ainda totalmente líquido; o odor geralmente era ácido-penetrante. A parte líquida tinha cor leitoso-acinzentada e a parte pastosa castanho-esverdea-da. No omaso também se observou conteúdo moderadamente ressecado, escurecido e bem aderido à mucosa. O conteúdo do intestino delgado se apresentava pastoso a líquido, por vezes espumoso, e com muco, de cor amarelo-gema, amareloacinzentado, marrom-amarelado ou verde-acinzentado, fétido ou havia apenas muco amarelado. $O$ ceco se apresentava dilatado e repleto de conteúdo líquido de coloração levemente marrom ou com conteúdo pastoso a semilíquido ou líquidoespumoso, marrom-amarelado e fétido. $O$ cólon apresentava conteúdo semilíquido a líquido, amarelo-esverdeado, marrom-amarelado, com muco tingido de sangue e fétido. Em um caso o conteúdo do cólon ascendente estava ressecado e aderido à mucosa.

O rúmen se apresentava distendido, com muitas petéquias na serosa e com os vasos da subserosa intensamente congestos. As papilas ruminais apresentavam-se vermelhas $\mathrm{e}$ agrupadas, em áreas irregulares do rúmen. $O$ epitélio se desprendia facilmente e em algumas áreas se destacava sob forma de placas (Fig. 2 e 3), deixando a própria avermelhada, mais evidenciada no átrio, em algumas áreas dos sacos dorsal e ventral e nos pilares. Também se observou leve edema difuso da parede do rúmen. As lesões do retículo e do omaso tinham o mesmo padrão daquelas encontradas no rúmen, muito embora tenham sido observadas com menor intensidade. Ainda se observou discreto edema das folhas do omaso. No abomaso, os vasos subserosos estavam congestos; havia leve edema da parede. A distribuição das lesões era irregular entre os animais e as lesões da mucosa consistiram, principalmente, de intensa congestão difusa ou irregular da mucosa, com diferentes nuances, desde vermelho claro até vermelho escuro, e de extensas áreas de necrose erosiva ou ulcerativa (Fig. 4), de coloração vermelho-escura até cinza-enegrecida; a superfície enegrecida saía com facilidade. Na mucosa, também havia áreas irregulares, elevadas e de cor amareloacinzentada de tamanhos variados e de contornos irregulares, envolvendo também as dobras, com deposição de mate-

Quadro 1. Intoxicação experimental pelas favas de Stryphnodendron obovatum, bovinos que morreram

\begin{tabular}{|c|c|c|c|c|c|c|c|c|c|}
\hline \multicolumn{2}{|c|}{ Bovino } & \multirow{2}{*}{$\begin{array}{c}\text { Período de } \\
\text { administração }\end{array}$} & \multirow{2}{*}{$\begin{array}{l}\text { Dose } \\
\text { diária } \\
(\mathrm{g} / \mathrm{kg})\end{array}$} & \multirow{2}{*}{$\begin{array}{l}\text { Dose } \\
\text { diária } \\
(\mathrm{g})\end{array}$} & \multirow{2}{*}{$\begin{array}{c}\text { Número de } \\
\text { dias de } \\
\text { ingestão }\end{array}$} & \multirow{2}{*}{$\begin{array}{l}\text { Dose } \\
\text { total } \\
(\mathrm{g} / \mathrm{kg})\end{array}$} & \multirow{2}{*}{$\begin{array}{c}\text { Total } \\
\text { ingerido } \\
(\mathrm{g})\end{array}$} & \multirow{2}{*}{$\begin{array}{c}\text { Início dos } \\
\text { sintomas } \\
\text { após a } 1^{\mathrm{a}} \\
\text { administração }\end{array}$} & \multirow{2}{*}{$\begin{array}{c}\text { Evolução } \\
\text { até a } \\
\text { morte }\end{array}$} \\
\hline $\mathrm{N}^{\circ}$ & $\begin{array}{r}\text { Peso } \\
(\mathrm{kg})\end{array}$ & & & & & & & & \\
\hline 840 & 117 & $23 / 11 / 98$ & 60 & 7.020 & 1 & 60 & 7.020 & $1^{\circ}$ dia & 4 dias \\
\hline 5210 & 130 & $30 / 11 / 93$ a $07 / 12 / 93$ & 10 & 1.300 & 8 & 80 & 10.400 & $1^{\mathrm{o}} \mathrm{dia}$ & 13 dias \\
\hline 4919 & 255 & $25 / 11 / 93$ a $27 / 11 / 93$ & 20 & 5.100 & 3 & 60 & 15.300 & $2^{\circ}$ dia & 6 dias \\
\hline 802 & 161 & $10 / 11 / 98$ a $11 / 11 / 98$ & 30 & 4.830 & 2 & 60 & 9.660 & $1^{\circ}$ dia & 6 dias \\
\hline 182 & 176 & 06/11/98 a 07/11/98 & 40 & 7.040 & 2 & 80 & 14.080 & $2^{\circ}$ dia & 3 dias \\
\hline
\end{tabular}



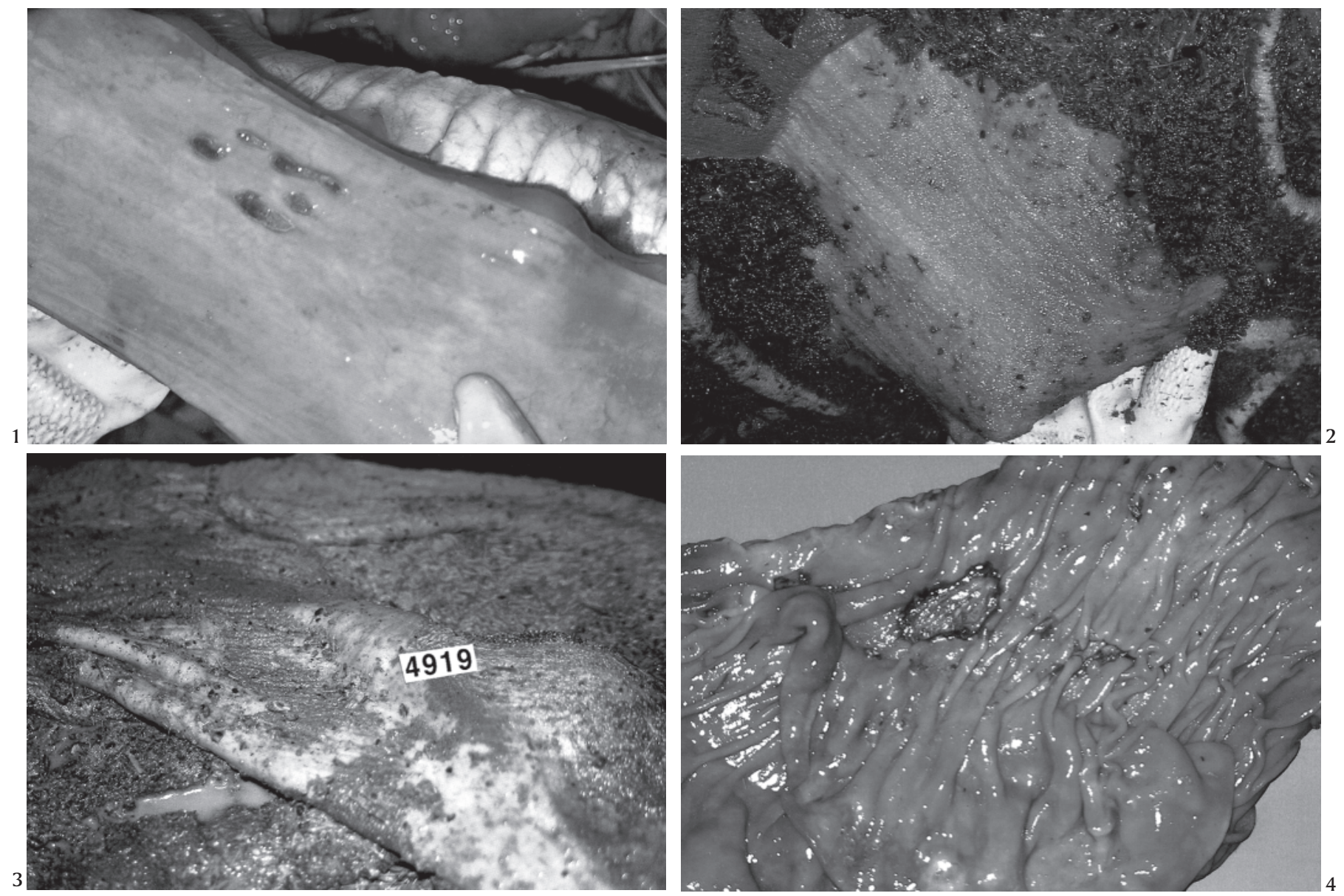

Fig. 1. Úlceras no terço médio do esôfago, na intoxicação experimental pelas favas de Stryphnodendron obovatum (Bovino 182).

Fig. 3. Áreas de desprendimento do epitélio, leve congestão, fragmentos das favas e conteúdo líquido, leitoso-acinzento no rúmen, na intoxicação experimental pelas favas de S. obovatum (Bovino 4919).

rial amarelado com aspecto ressecado, marrom-acinzentado ou enegrecido sobre as áreas necrosadas (Fig. 5).

A mucosa do intestino delgado se apresentava irregularmente vermelha com intensidades variadas nos diferentes segmentos; por vezes as placas de Peyer estavam intensamente vermelhas, bem delimitadas, levemente salientes (Fig. 6), sobre uma mucosa levemente avermelhada e espessada ou havia moderada congestão do duodeno, bem como discreta congestão em áreas irregulares do jejuno e do íleo. Na mucosa do ceco havia leve a intensa congestão difusa ou em áreas irregulares e, em um dos bovinos, havia uma grande área intensamente vermelha, de limites irregulares; a válvula íleo-cecal se apresentava edemaciada e com alguns pontos vermelhos sobre um fundo enegrecido. A mucosa do cólon apresentava áreas irregulares de congestão, com algumas equimoses. Em um dos bovinos notou-se ainda a presença de duas áreas elevadas e escuras, que ao serem tracionadas, se destacavam sob forma de pseudomembranas; em outro, o

Fig. 2. Desprendimento do epitélio do rúmen e severa congestão da própria e dos pilares, na intoxicação experimental pelas favas de S. obovatum (Bovino 182).

Fig. 4. Congestão, hemorragia e úlceras no abomaso, na intoxicação experimental pelas favas de S. obovatum (Bovino 802).

cólon tinha a mucosa intensamente congesta onde o conteúdo estava aderido. No reto as áreas vermelhas da mucosa eram raras. Os linfonodos mesentéricos apresentavam-se avermelhados ao corte. Havia congestão dos vasos mesentéricos e dos vasos da subserosa do intestino delgado.

O figado estava levemente mais claro e friável, ou com áreas mais claras e de contornos irregulares, ou ainda discretamente congesto. No baço de um dos bovinos havia áreas de infarto, em outro estava levemente aumentado de volume. Nos dois bovinos que apresentaram pneumonia por aspiração havia moderada quantidade de muco na traquéia e áreas compactas, irregulares, vermelhas e levemente salientes nos lobos pulmonares. Os demais órgãos não apresentaram lesões significativas.

\section{Achados histopatológicos (Quadros 2 a 6)}

No epitélio, o exame histológico revelou discreta a moderada paraqueratose da mucosa oral e língua (Fig. 7) e leve 

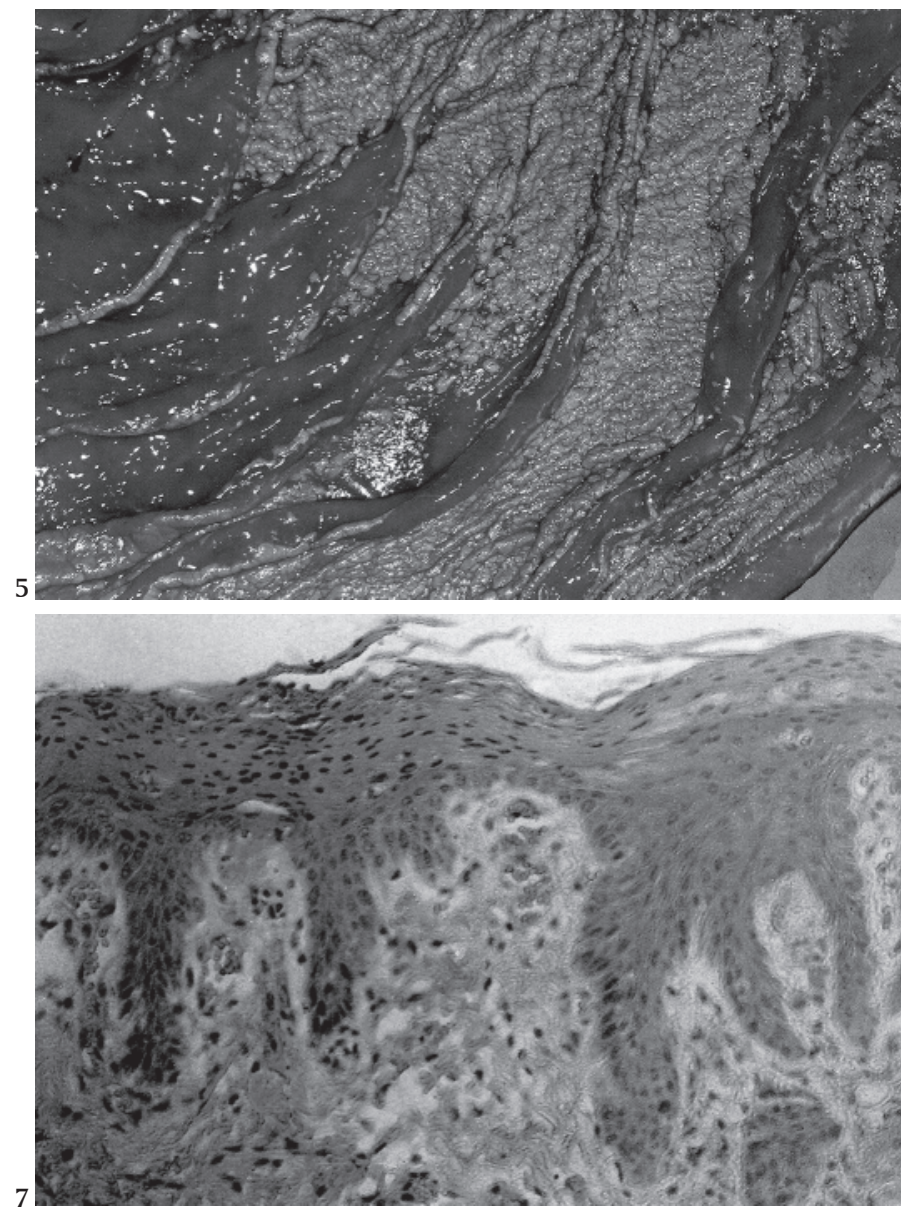

Fig. 5. Congestão, hemorragia e necrose no abomaso, na intoxicação experimental pelas favas de S. obovatum (Bovino 840).

Fig. 7. Paraqueratose da língua, na intoxicação experimental pelas favas de S. obovatum (Bovino 802). HE. Obj. 25.

a acentuada paraqueratose do esôfago até o omaso, além de hiperqueratose leve a moderada nos pré-estômagos. Erosões e úlceras ocorreram variavelmente entre os animais, nos diversos segmentos do trato gastrintestinal. Acantose foi verificada desde a mucosa oral e língua até o omaso, em graus que variaram de leve a moderado, na maioria das vezes em focos. Espongiose epitelial focal foi verificada desde a língua até o omaso, variando em intensidade, de discreta a moderada. Da mucosa oral até o abomaso notou-se que muitas vezes algumas células epiteliais, isoladamente, apresentavamse vacuolizadas, porém a lesão epitelial era predominantemente degenerativa, do tipo hidrópico/vacuolar (Fig. 8), verificada mais acentuadamente do rúmen ao omaso, com formação de vesículas e/ou vesículo-pústulas intra-epiteliais, dentro das quais, às vezes, havia derrame sero-fibrinoso (Fig. 9) e/ou a presença de polimorfonucleares e de queratinócitos acantolíticos (Fig. 10). Estes também estavam presentes fora das vesículas e em áreas de necrose epitelial, que muitas vezes afetava todos os estratos do epitélio; outras vezes os
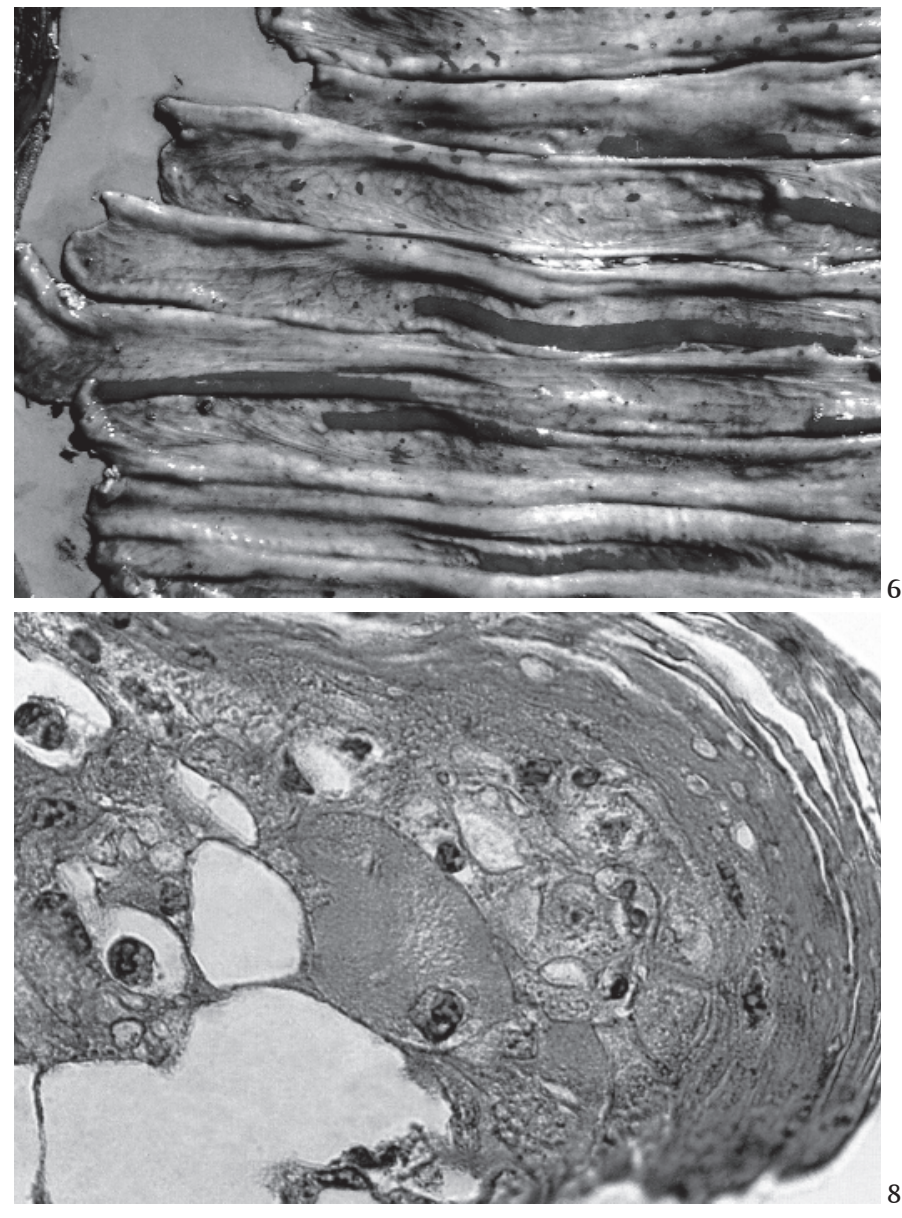

Fig. 6. Placas de Peyer intensamente vermelhas, bem delimitadas e levemente salientes, no intestino delgado, na intoxicação experimental pelas favas de S. obovatum (Bovino 840).

Fig. 8. Degeneração hidrópico-vacuolar no epitélio ruminal, na intoxicação experimental pelas favas de S. obovatum em bovino. HE, obj. 100.

queratinócitos se apresentavam em grupos, ou dispersos em meio aos detritos celulares da necrose epitelial e dos restos de células inflamatórias. $O$ desprendimento epitelial com formação de fendas supra ou infrabasilares, também ocorreu mais freqüientemente do rúmen ao omaso. A resposta inflamatória epitelial tinha predominância de células polimorfonucleares, algumas vezes se observavam numerosos eosinófilos, inclusive no abomaso. Invasão bacteriana intraepitelial ocorreu nas áreas de erosão ou ulceração da mucosa oral, língua, pré-estômagos e abomaso, especialmente naquelas áreas cuja degeneração e necrose epitelial eram mais acentuadas. Observaram-se congestão e hemorragia epitelial do abomaso (Fig. 11) ao reto, porém eram mais intensas do abomaso ao intestino delgado. A presença de pigmento castanho-amarelado na superfície epitelial, invadindo o epitélio e dentro de macrófagos foi observada em todo trato gastrintestinal; em algumas áreas este pigmento penetrou o interior de vasos da submucosa. Nas Placas de Peyer se observou congestão e a presença de macrófagos contendo 
Quadro 2. Alterações macroscópicas do sistema digestivo na intoxicação experimental pelas favas de Stryphnodendron obovatum em bovinos (doses diárias)

\begin{tabular}{|c|c|c|c|c|c|c|c|c|c|c|}
\hline \multirow[t]{2}{*}{ Mucosa } & \multicolumn{2}{|c|}{$\begin{array}{l}\text { Bovino } 840 \\
60 \mathrm{~g} / \mathrm{kg} / 1 \mathrm{dia}\end{array}$} & \multicolumn{2}{|c|}{$\begin{array}{c}\text { Bovino } 5210 \\
10 \mathrm{~g} / \mathrm{kg} / 8 \text { dias } \\
\end{array}$} & \multicolumn{2}{|c|}{$\begin{array}{l}\text { Bovino } 4919 \\
20 \mathrm{~g} / \mathrm{kg} / 3 \text { dias }\end{array}$} & \multicolumn{2}{|c|}{$\begin{array}{c}\text { Bovino } 802 \\
30 \mathrm{~g} / \mathrm{kg} / 2 \text { dias }\end{array}$} & \multicolumn{2}{|c|}{$\begin{array}{c}\text { Bovino } 182 \\
40 \mathrm{~g} / \mathrm{kg} / 2 \text { dias }\end{array}$} \\
\hline & Alterações & Conteúdo & Alterações & Conteúdo & Alterações & Conteúdo & Alterações & Conteúdo & Alterações & Conteúdo \\
\hline Rúmen & $\begin{array}{l}\text { Papilas }{ }^{\mathrm{d} / \mathrm{sv}} \\
\text { congestas }\end{array}$ & $\begin{array}{l}\text { Pastoso-líquido, } \\
\text { e não; leitoso- } \\
\text { acinzenzentado; } \\
\text { odor ácido; se- } \\
\text { mentes visíveis }\end{array}$ & $\begin{array}{l}\text { Congestão e } \\
\text { agrupamento } \\
\text { de papilas }^{\text {assv }}\end{array}$ & Ressecado+ & $\begin{array}{l}\text { Desprendimen- } \\
\text { to do epitélio }{ }^{\mathrm{a} / \mathrm{pi}} \\
+++; \text { conges- } \\
\text { tão }++; \text { edema } \\
\text { da parede+ }\end{array}$ & $\begin{array}{l}\text { Líquido; lei- } \\
\text { toso-acinzen- } \\
\text { tado; odor pú- } \\
\text { trido; semen- } \\
\text { tes visíveis }\end{array}$ & $\begin{array}{l}\text { Desprendimen- } \\
\text { to do epitélio }{ }^{\mathrm{qr}} \text {; } \\
\text { congestão }^{\mathrm{vv}}+/++\end{array}$ & $\begin{array}{l}\text { Pastoso-líqui- } \\
\text { do; leitoso- } \\
\text { acinzentado; } \\
\text { odor ácido; se- } \\
\text { mentes visíveis }\end{array}$ & $\begin{array}{l}\text { Desprendimen- } \\
\text { to do epitélioq }{ }^{\text {rF; }} \\
\text { congestão }^{\text {pissv }}\end{array}$ & $\begin{array}{l}\text { Odor ácido; } \\
\text { visíveis }\end{array}$ \\
\hline Retículo & $\begin{array}{l}\text { Desprendimen- } \\
\text { to do epitélio }{ }^{\mathrm{qr}}\end{array}$ & $\begin{array}{l}\text { Sementes vi- } \\
\text { síveis }\end{array}$ & $-*$ & - & $\begin{array}{l}\text { Desprendi- } \\
\text { mento do epité- } \\
\text { lio }+++; \text { con- } \\
\text { gestão/hemorra- } \\
\text { gia }++\end{array}$ & $\begin{array}{l}\text { Líquido; lei- } \\
\text { toso-acinzen- } \\
\text { tado; odor á- } \\
\text { cido; semen- } \\
\text { tes visíveis }\end{array}$ & $\begin{array}{l}\text { Desprendimen- } \\
\text { to do epitélio }^{\mathrm{rr}} ; \\
\text { congestão }^{\text {ir }}\end{array}$ & $\begin{array}{l}\text { Pastoso-líqui- } \\
\text { do; leitoso- } \\
\text { acinzentado; } \\
\text { odor ácido; se- } \\
\text { mentes visíveis }\end{array}$ & $\begin{array}{l}\text { Desprendimen- } \\
\text { to do epitélio } \\
\text { congestão }^{\mathrm{p} / \mathrm{sv}}\end{array}$ & $\begin{array}{l}\text { Odor ácido; } \\
\text { sementes vi- } \\
\text { síveis }\end{array}$ \\
\hline Omaso & $\begin{array}{l}\text { Desoprendimen- } \\
\text { to do epitélio }{ }^{\mathrm{qr}}+\text {; } \\
\text { congestão }\end{array}$ & $\begin{array}{l}\text { Sementes vi- } \\
\text { síveis }\end{array}$ & Congestão $^{\text {ir }}+$ & $\begin{array}{l}\text { Ressecado ++; } \\
\text { aderido à mucosa }\end{array}$ & $\begin{array}{l}\text { Desprendi- } \\
\text { mento do epité- } \\
\text { lio }+++; \text { con- } \\
\text { gestãod }++; \text { ede- } \\
\text { ma das folhas }+\end{array}$ & $\begin{array}{l}\text { Líquido; leito- } \\
\text { so-acinzentado; } \\
\text { odor ácido; se- } \\
\text { mentes visíveis }\end{array}$ & $\begin{array}{l}\text { Desprendimen- } \\
\text { to do epitélio }{ }^{\mathrm{qr}}\end{array}$ & - & $\begin{array}{l}\text { Desprendimen- } \\
\text { to do epitéliogr }+ \text {; } \\
\text { congestão }^{\text {pisvs }}\end{array}$ & $\begin{array}{l}\text { Odor ácido; } \\
\text { sementes vi- } \\
\text { síveis }\end{array}$ \\
\hline Abomaso & $\begin{array}{l}\text { Congestão }{ }^{\mathrm{H}}+++ \\
\text { necrose do epité- } \\
\text { lio }++/+++\end{array}$ & $\begin{array}{l}\text { Pastoso-firme; } \\
\text { sementes visí- } \\
\text { veis }\end{array}$ & $\begin{array}{l}\text { Congestão }{ }^{\mathrm{d}} / \text { he- } \\
\text { morragiai }++; \\
\text { erosões/úlce- } \\
\text { ras }^{\mathrm{p}+}\end{array}$ & - & $\begin{array}{l}\text { Edemad }^{\mathrm{d}}+; \text { con- } \\
\text { gestão }^{\mathrm{d}}++; \text { ne- } \\
\text { crose }++; \text { ero- } \\
\text { sões/úlceras }++\end{array}$ & $\begin{array}{l}\text { Líquido; leito- } \\
\text { so-acinzentado; } \\
\text { odor ácido; se- } \\
\text { mentes visíveis }\end{array}$ & $\begin{array}{l}\text { Congestãod/he- } \\
\text { morragiai }+++; \\
\text { erosões/úlceras } \\
+++; \text { necrose }^{p}++\end{array}$ & $\begin{array}{l}\text { Sólido; odor áci- } \\
\text { do; sementes vi- } \\
\text { síveis }\end{array}$ & $\begin{array}{l}\text { Congestão }{ }^{\mathrm{d}}++; \\
\text { necrose }++\end{array}$ & $\begin{array}{l}\text { Sementes vi- } \\
\text { síveis }\end{array}$ \\
\hline Duodeno & Congestão $+/++$ & Líquido & - & $\begin{array}{l}\text { Vazio; com muco } \\
\text { amarelo }\end{array}$ & $\begin{array}{l}\text { Congestão }++ \\
1+++\end{array}$ & $\begin{array}{l}\text { Líquido; marrom- } \\
\text { amarelado; odor } \\
\text { pútrido; semen- } \\
\text { tes visíveis }\end{array}$ & Congestão $^{\text {ir }}+/++$ & & $\begin{array}{l}\text { Congestão/he- } \\
\text { morragiai }^{\text {in }}++ \\
1+++\end{array}$ & $\begin{array}{l}\text { Espumoso; a- } \\
\text { marelo-gema }\end{array}$ \\
\hline Jejuno & $\begin{array}{l}\text { Congestão/hemor- } \\
\text { ragia das placas }\end{array}$ & $\begin{array}{l}\text { - Mucoso, amare- } \\
\text { lo-gema }\end{array}$ & - & $\begin{array}{l}\text { Vazio; com muco } \\
\text { amarelo }\end{array}$ & Congestão + & $\begin{array}{l}\text { Líquido-espumo- } \\
\text { so; marrom-ama- } \\
\text { relado; odor pú- } \\
\text { trido }\end{array}$ & Congestão $^{\text {ir }}+/++$ & $\begin{array}{l}\text { Mucoso; amare- } \\
\text { lo-acinzentado/ } \\
\text { verde-acinzenta- } \\
\text { do }\end{array}$ & $\begin{array}{l}\text { Congestão/he- } \\
\text { morragia }^{\text {ir }}++/ \\
+++\end{array}$ & $\begin{array}{l}\text { Espumoso; a- } \\
\text { marelo-gema }\end{array}$ \\
\hline Íleo & Congestão ${ }^{\mathrm{d}}+$; & Líquido & - & Vazio; com muco & Congestão+ & $\begin{array}{l}\text { Líquido-espumo- } \\
\text { so; marrom-ama- } \\
\text { relado; odor pú- } \\
\text { trido }\end{array}$ & $\begin{array}{l}\text { Congestão }++1 \\
+++\end{array}$ & - & $\begin{array}{l}\text { Congestão/he- } \\
\text { morragia }{ }^{\text {ir }}++/ \\
+++\end{array}$ & $\begin{array}{l}\text { Espumoso; a- } \\
\text { marelo-gema }\end{array}$ \\
\hline Ceco & $\begin{array}{l}\text { Congestão }{ }^{\mathrm{ir}}++ \text {; } \\
\text { necrose }^{\mathrm{i}}++; \mathrm{e}- \\
\text { dema, necrose e } \\
\text { hemorragia da } \\
\text { válvula íleo-cecal }\end{array}$ & Líquido & - & $\begin{array}{l}\text { Escasso; semi-lí- } \\
\text { quido/pastoso }\end{array}$ & - & $\begin{array}{l}\text { Líquido-espumo- } \\
\text { so;marrom-ama- } \\
\text { relado; odor pú- } \\
\text { trido }\end{array}$ & Congestão $^{d}+++$ & Líquido: marrom & Congestão $^{\text {ir }}+/++$ & - \\
\hline Cólon & $\begin{array}{l}\text { Congestão } \mathrm{ir} / \text { he- } \\
\text { morragia }++; \\
\text { necrose }+/++\end{array}$ & $\begin{array}{l}\text { Líquido/semi-lí- } \\
\text { quido; com mu- } \\
\text { co }^{\dagger} \text { amarelo-es- } \\
\text { verdeado }\end{array}$ & - & Escasso; pastoso & $\begin{array}{l}\text { Congestão/he- } \\
\text { morragia }+/++\end{array}$ & $\begin{array}{l}\text { Pastoso/resseca- } \\
\text { do; marrom-ama- } \\
\text { relado; odor pú- } \\
\text { trido; aderido à } \\
\text { mucosa }\end{array}$ & - & Escasso & Congestão $o^{\text {ir }}+/++$ & - \\
\hline Reto & Congestão/he- & Escasso e pastoso & & - & - & - & Congestão ${ }^{\text {ir }}+$; & Vazio & Congestão $^{\mathrm{ir}}+/++$ & - \\
\hline
\end{tabular}

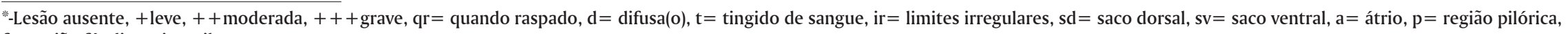
$\mathrm{f}+$ região fúndica, pi+. pilares. 
Quadro 3. Alterações histológicas do sistema digestivo do Bovino 182, na intoxicação experimental pelas favas de Stryphnodendron obovatum

\begin{tabular}{|c|c|c|c|c|c|c|c|c|c|c|c|c|}
\hline \multirow[t]{2}{*}{ Alterações } & \multicolumn{10}{|c|}{ Órgãos/Lesões* } & \multirow[b]{2}{*}{ Cólon } & \multirow[b]{2}{*}{ Reto } \\
\hline & Língua & Esôfago & Rúmen & Retículo & Omaso & Abomaso & Duodeno & Jejuno & Íleo & Ceco & & \\
\hline \multicolumn{13}{|l|}{ Epitélio } \\
\hline Paraqueratose & + & + & $+/++$ & - & + & - & - & - & - & - & - & - \\
\hline Hiperqueratose & - & - & $+/++$ & + & - & - & - & - & - & - & - & - \\
\hline Ulceração & - & - & +++ & - & - & - & - & - & - & - & - & - \\
\hline Erosão & + & + & - & - & - & $++^{\mathrm{f}}$ & ++ & ++ & ++ & + & $+/++$ & + \\
\hline Acantose & - & - & $+/++$ & $t^{\mathrm{f}}$ & + & - & - & - & - & - & - & - \\
\hline Espongiose & $+^{\mathrm{f}}$ & - & $+/++$ & $+/++$ & $+/++$ & - & - & - & - & - & - & - \\
\hline Tumefação/vacuolização de células isoladas & + & + & + & $+/++$ & + & +++ & - & - & - & - & - & - \\
\hline Degeneração hidrópico-vacuolar & $+/++$ & + & $++/+++$ & $+/++$ & $++/+++$ & - & - & - & - & - & - & - \\
\hline Formação de vesículas & - & - & $+/++$ & $+/++$ & $++^{\mathrm{vp}}$ & - & - & - & - & - & - & - \\
\hline Formação de fendas & - & + & $+/+++$ & - & $++/+++$ & - & - & - & - & - & - & - \\
\hline Necrose & - & - & $++/+++$ & $+/++$ & $++/+++$ & ++ & $++^{\text {se }}$ & $++/+++^{\mathrm{se}}$ & $++^{\text {se }}$ & $+/++$ & $+/++$ & ++ \\
\hline Queratinócitos acantolíticos & - & - & - & - & $++/+++$ & - & - & - & - & - & - & - \\
\hline Infiltração por polimorfonucleares & - & - & $++^{\mathrm{e}}$ & $++^{\mathrm{e}}$ & $+/+++^{e}$ & $++/++++^{e}$ & & - & $\cdot$ & - & - & $\cdot$ \\
\hline Inflitração por mononucleares & - & - & ++ & & ++ & $+/++$ & - & - & - & - & - & - \\
\hline Invasão bacteriana & - & $++/+++$ & $+/++$ & $+/++$ & ++ & ++ & + & $+/++$ & + & + & $+/++$ & + \\
\hline Congestão & - & - & - & - & - & $++/+++$ & +++ & +++ & +++ & $+/++$ & $+/++$ & $+/++$ \\
\hline Pigmento castanho na superfície & - & + & $+/++$ & ++ & $+/++$ & + & + & + & + & $+/++$ & $++/+++$ & ++ \\
\hline Pigmento castanho dentro do epitélio & - & + & $+/++$ & + & + & - & - & - & - & - & - & - \\
\hline Hiperplasia de células basais & + & - & + & - & $+/++^{\mathrm{f}}$ & - & - & - & - & - & - & - \\
\hline Infiltração por células polimorfonucleares & - & - & - & - & - & ++ & ++ & ++ & $++^{e}$ & $++^{\mathrm{e}}$ & $+^{\mathrm{f}}$ & \\
\hline Infiltração por células mononucleares & - & - & - & - & - & - & $+/++$ & $+/++^{\mathrm{f}}$ & $+/++$ & + & $+^{\mathrm{f}}$ & $+^{\mathrm{f}}$ \\
\hline Hemorragia & - & - & - & - & - & - & +++ & +++ & +++ & $+/++^{\mathrm{f}}$ & $+/++^{\mathrm{f}}$ & $+/++^{f}$ \\
\hline Pigmento castanho invadindo o epitélio & - & - & - & - & - & - & - & - & $+/++$ & $++/+++$ & + & - \\
\hline \multicolumn{13}{|l|}{ Lâmina própria } \\
\hline Congestão & ++ & ++ & $+/++$ & $+/++$ & $+/++$ & +++ & +++ & +++ & +++ & + & + & + \\
\hline Edema & - & ++ & ++ & ++ & $+/++$ & - & - & - & - & - & - & - \\
\hline Fibrina & + & +++ & - & - & - & - & - & - & - & - & - & - \\
\hline Infiltração por polimorfonucleares & $+^{e}$ & $++/+++^{e}$ & & $++^{\mathrm{e}}$ & $+/++^{\mathrm{e}}$ & $++^{e}$ & ++ & ++ & ++ & $++^{\mathrm{e}}$ & $++^{\mathrm{e}}$ & $+^{\mathrm{f}}$ \\
\hline Infiltração por células mononucleares & $++^{\mathrm{pv}}$ & ++ & $+/++$ & + & $+/++$ & $+/++$ & $+/++$ & $+/++$ & $+/++$ & - & - & - \\
\hline Hemorragia & & & & & & & +++ & +++ & +++ & - & - & - \\
\hline Placas de Peyer com macrófagos contendo & - & - & - & + & + & + & - & - & - & - & - & - \\
\hline
\end{tabular}
pigmento castanho 
Quadro 4. Alterações histológicas do sistema digestivo do Bovino 840, na intoxicação experimental pelas favas de Stryphnodendron obovatum

\begin{tabular}{|c|c|c|c|c|c|c|c|c|c|c|c|c|}
\hline \multirow[t]{2}{*}{ Alterações } & \multicolumn{9}{|c|}{ Órgãos/Lesões* } & \multirow[b]{2}{*}{ Ceco } & \multirow[b]{2}{*}{ Cólon } & \multirow[b]{2}{*}{ Reto } \\
\hline & $\begin{array}{c}\text { Mucosa } \\
\text { oral }\end{array}$ & Língua & Rúmen & Retículo & Omaso & Abomaso & Duodeno & Jejuno & Íleo & & & \\
\hline
\end{tabular}

Epitélio

Paraqueratose

Hiperqueratose

Ulceração

Erosão

Acantose

Espongiose

Tumefação/vacuolização de células epiteliais isoladas

Degeneração hidrópico-vacuolar

Formação de vesículas

Fibrina intra-epitelia

Formação de fendas

Necrose

Detritos celulares

Queratinócitos acantolíticos

Infiltração por polimorfonucleares

Inflitração por mononucleares

Invasão bacteriana

Congestão

Hemorragia

Pigmento castanho na superfície

Pigmento castanho dentro do epitélio

Hiperplasia de células basais

(n)

\section{Lâmina própria}

Congestão

Hemorragia

Edema

Fibrina

Infiltração por polimorfonucleares

Infiltração por mononucleares

Hemorragia

Inflitração por macrófagos nos folículos linfóides

Macrófagos no centro de Placas de Peyer

$\begin{array}{cccccc}++ & ++/+++ & ++ & ++ & ++/+++ & - \\ - & - & + & - & + & - \\ ++/+++ & - & - & + & +/++ & +/++ \\ + & - & - & - & ++ & ++ \\ +/++ & ++ & ++ & +^{\mathrm{f}} & ++ & - \\ - & +/++ & +/++ & +/++ & - & - \\ + & +/++ & + & +/++ & ++ & + \\ - & + & ++/+++ & + & ++ & ++ \\ - & - & +/++ & - & ++/+++ & + \\ - & - & ++ & - & ++ & - \\ + & - & ++ & +++ & +/+++ & - \\ +++ & +\mathrm{f} & ++/+++ & ++ & ++/+++ & +++ \\ +++ & ++^{\mathrm{f}} & +/++ & + & +/++ & +++ \\ - & - & ++ & + & +/+++ & - \\ - & - & ++ & +/++ & +++ & +++ \\ - & - & + & + & + & +++ \\ ++/++ & - & + & +/++ & + & ++/+++ \\ - & - & - & - & - & +++ \\ - & - & - & - & - & ++ \\ ++ & - & +++ & +/++ & +/++ & +/++ \\ +++ & - & +/++ & + & +/++ & ++ \\ - & + & +/++ & +/++\mathrm{f} & +/++ & - \\ & & & & & \end{array}$

"-Lesão ausente, +leve, ++ moderada, +++ grave, $\mathrm{f}=$ focal, $\mathrm{e}=$ com predominância de eosinófilos, $\mathrm{se}=$ na metade superior do epitélio. 
Quadro 5. Alterações histológicas do sistema digestivo do Bovino 802, na intoxicação experimental pelas favas de Stryphnodendron obovatum

\begin{tabular}{|c|c|c|c|c|c|c|c|c|c|c|c|}
\hline \multirow[t]{2}{*}{ Alterações } & \multicolumn{8}{|c|}{ Órgãos/Lesões" } & \multirow[b]{2}{*}{ Ceco } & \multirow[b]{2}{*}{ Cólon } & \multirow[b]{2}{*}{ Reto } \\
\hline & Língua & Rúmen & Retículo & Omaso & Abomaso & Duodeno & Jejuno & Íleo & & & \\
\hline \multicolumn{12}{|l|}{ Epitélio } \\
\hline Paraqueratose & $++/+++{ }^{d}$ & $+/++$ & - & $t^{\mathrm{f}}$ & - & - & - & - & - & - & - \\
\hline Hiperqueratose & & - & + & + & $++/+++$ & - & - & - & - & - & - \\
\hline Erosão & $+1++$ & - & - & ++ & $+/++$ & $+/++$ & + & ++ & $++/+++$ & + & - \\
\hline Acantose & & - & $+/++^{\mathrm{f}}$ & - & - & - & - & - & - & - & - \\
\hline Espongiose & $++/+++{ }^{d}$ & $+1++$ & $+/++$ & - & - & - & - & - & - & - & - \\
\hline Tumefação/vacuolização de células epiteliais isoladas & + & ++ & ++ & $+/++$ & - & - & - & - & - & - & - \\
\hline Degeneração hidrópico-vacuolar & - & $++/+++$ & + & $++/+++$ & - & - & - & - & - & - & - \\
\hline Formação de vesículas & - & $+/++$ & - & $+++\mathrm{vp}$ & - & - & - & - & - & - & - \\
\hline Fibrina intra-epitelial & - & ++ & - & ++ & - & - & - & - & - & - & - \\
\hline Formação de fendas & - & ++ & + & $++/+++$ & $++/+++$ & - & - & - & - & - & - \\
\hline Necrose/detritos celulares & - & $+/++$ & $+/++$ & $++/+++$ & $+/+++$ & - & - & - & - & - & - \\
\hline Queratinócitos acantolíticos & - & $+1++$ & - & $++1+++$ & - & - & - & - & - & - & - \\
\hline Infiltração por polimorfonucleares & - & ++ & $+/++^{e}$ & + & $+/+++^{e}$ & $+^{\mathrm{e}}$ & $++^{\mathrm{e}}$ & $+^{\mathrm{e}}$ & - & $++/++^{e}$ & - \\
\hline Inflitração por mononucleares & + & - & $+/++$ & - & ++ & $+/++$ & + & + & + & $+/+++$ & + \\
\hline Invasão bacteriana & - & + & + & $+/++$ & $+/++$ & - & + & - & $++^{\mathrm{f}}$ & $++^{\mathrm{f}}$ & $++^{\mathrm{f}}$ \\
\hline Congestão & - & - & - & - & +++ & $++/+++$ & $++/+++$ & $++/+++$ & $++/+++$ & $++/+++$ & $++/+++$ \\
\hline Pigmento castanho na superfície & - & $+/++$ & + & ++ & + & + & +++ & + & ++ & $+/++$ & ++ \\
\hline Pigmento castanho invadindo o epitélio & - & $+/++$ & + & ++ & + & + & ++ & + & $++/+++v s$ & $+/++$ & $+/++$ \\
\hline Necrose & - & - & - & - & - & + & - & - & - & $+/++$ & - \\
\hline Hemorragia & - & - & - & - & - & + & - & - & - & $+/++$ & - \\
\hline \multicolumn{12}{|l|}{ Lâmina própria } \\
\hline Congestão & ++ & ++ & $+/++$ & ++ & ++ & $++/+++$ & $++/+++$ & $++/+++$ & $++/+++$ & $++/+++$ & $++/+++$ \\
\hline Hemorragia & $t^{\mathrm{f}}$ & ++ & - & - & - & - & - & - & - & - & - \\
\hline Edema & + & ++ & - & $+/++$ & - & - & - & - & - & - & - \\
\hline Infiltração por polimorfonucleares & - & $+^{e}$ & $+^{e}$ & - & - & - & - & - & $+^{\mathrm{e}}$ & - & - \\
\hline Infiltração por mononucleares & $+/++$ & $+/++$ & + & $+/++$ & - & - & - & - & - & - & - \\
\hline Macrófagos contendo pigmento no centro de folículos & - & - & - & - & - & $+/++$ & - & - & - & - & - \\
\hline Inflitração por células mononucleares & - & - & - & - & - & $+/++$ & $+/++$ & $+/++$ & - & - & - \\
\hline Macrófagos contendo pigmento castanho & - & - & - & - & - & - & +++ & - & - & - & - \\
\hline Congestão das Placas de Peyer & - & - & - & - & - & - & ++ & + & - & - & - \\
\hline Necrose nas Placas de Peyer & - & - & - & - & - & - & ++ & + & - & - & - \\
\hline
\end{tabular}

"-Lesão ausente, +leve, ++ moderada, +++ grave, $\mathrm{f}=$ focal, e= com predominância de eosinófilos, vs= até dentro de vasos sanguíneos, vp= vesículo-pústulas. 


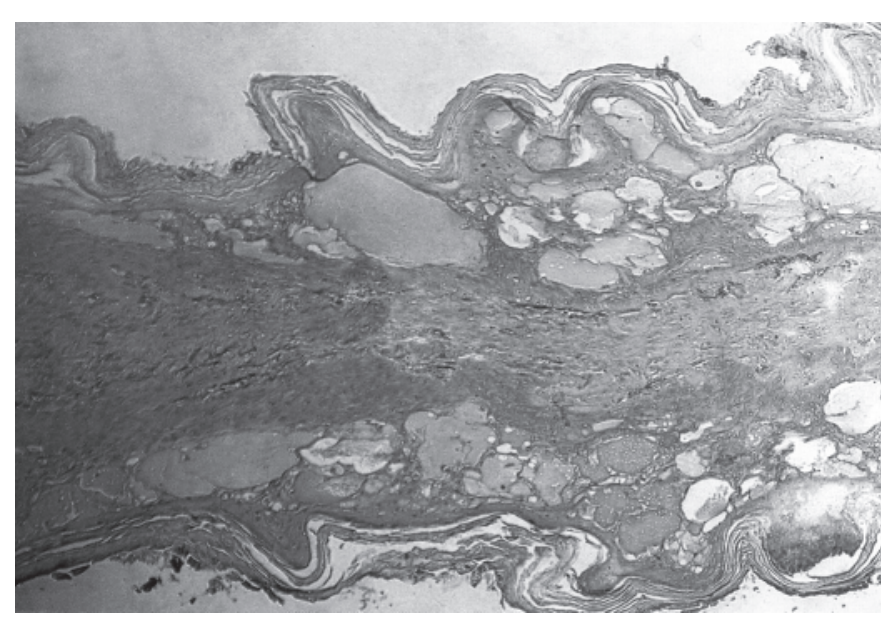

Fig. 9. Degeneração e necrose no epitélio do omaso; numerosas vesículas confluentes, de conteúdo sero-fibrinoso, na intoxicação experimental pelas favas de S. obovatum. HE, obj. 25.

pigmento castanho-amarelado e, por vezes, necrose com presença de carriorrexia e detritos celulares.

Na camada basal do epitélio, além das fendas, observou-se hiperplasia focal, desde a língua até o omaso, muito embora esta lesão tenha sido mais acentuada nos pré-estômagos, apresentando também proliferações digitiformes focais (rete ridges).

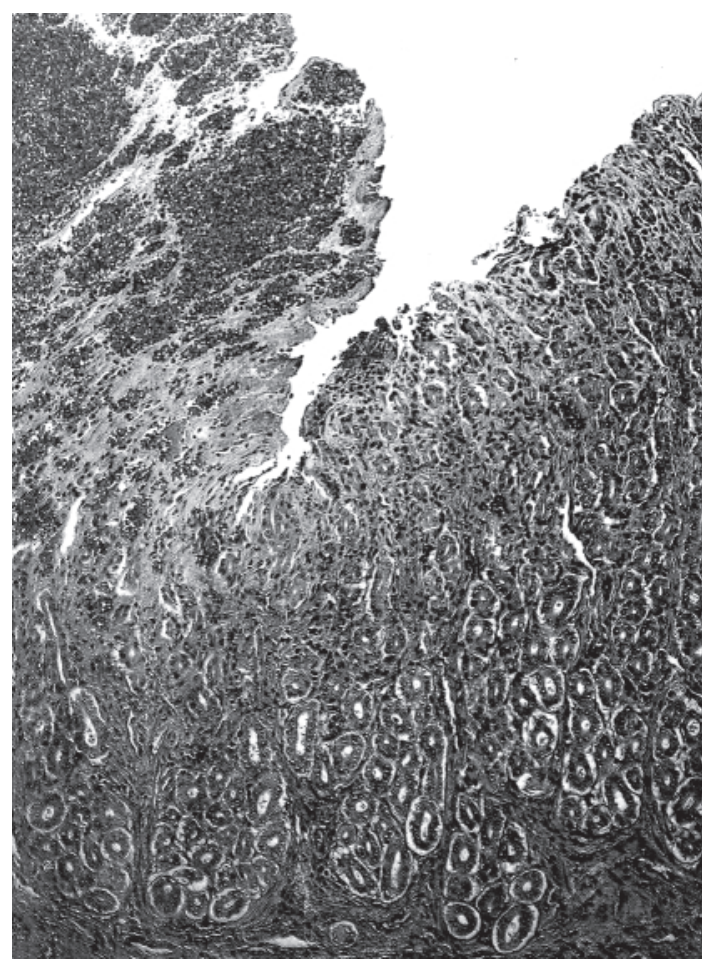

Fig. 11. Necrose, congestão e hemorragia no epitélio do abomaso, na intoxicação experimental pelas favas de $S$. obovatum em bovinos. HE, obj. 25.

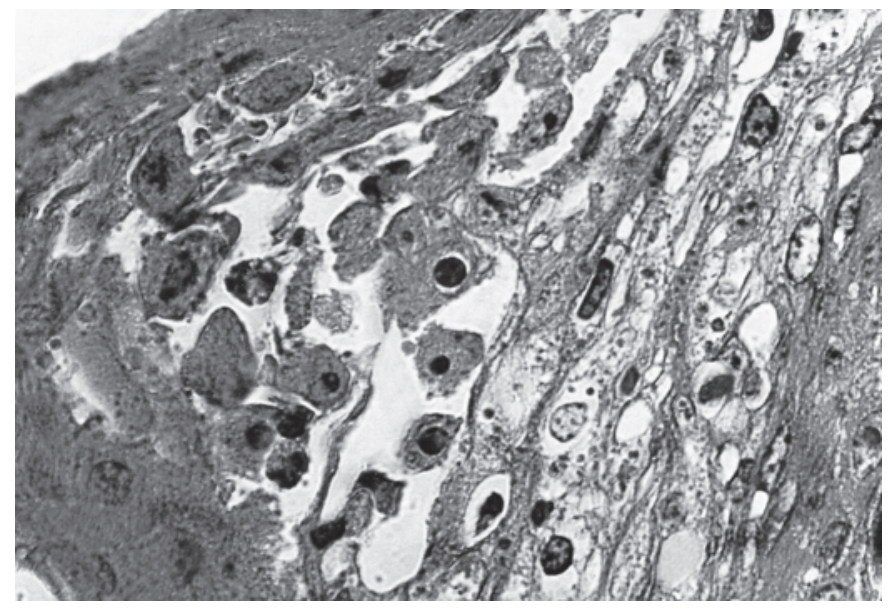

Fig. 10. Queratinócitos acantolíticos dispersos em meio às células degeneradas e necróticas do epitélio ruminal, na intoxicação experimental pelas favas de S. obovatum em bovino. HE, obj. 100 .

A lâmina própria, desde a mucosa oral até o reto apresentou congestão leve a severa, e em algumas áreas, hemorragias. Edema, derrame sero-fibrinoso e reação inflamatória, às vezes predominando células polimorfonucleares, outras vezes mononucleares, ocorreram predominantemente em pontos de ulceração, desde a mucosa oral até o intestino delgado. No intestino grosso, edema e fibrina raramente foram observados na lâmina própria, e a infiltração inflamatória era mais discreta do que nos outros segmentos.

Nos linfonodos mesentéricos havia congestão, hemorragia e hemossiderose e os macrófagos continham pigmento castanho-amarelado, algumas vezes no centro folicular, outras na região medular. Em alguns havia derrame sero-fibrinoso e a presença de macrófagos espumosos. Em alguns folículos em necrose notavam-se picnose, cariorrexia e detritos celulares.

\section{DISCUSSÃO E CONCLUSÕES}

Apesar de as favas das três espécies de Stryphnodendron afetarem principalmente o tubo digestivo, há particularidades em relação às lesões provocadas por cada uma dessas espécies, muito embora as lesões macro e microscópicas do trato gastrintestinal dos bovinos intoxicados por S. obovatum tenham sido mais graves.

$\mathrm{Na}$ intoxicação por $S$. coriaceum em bovinos os principais achados de necropsia foram edema do mesentério e da parede intestinal, ressecamento do conteúdo dos pré-estômagos, fígado amarelado e rins pálidos. À histopatologia as principais alterações foram tumefação e necrose incipiente de hepatócitos e alterações na filtração glomerular (Döbereiner \& Canella 1956, Tokarnia et al. 1991, 2000). Nos caprinos, a necropsia revelou que, além das alterações erosivas e ulcerativas, desde a boca até o rúmen, houve desprendimento da superfície mucosa do rúmen e retículo. Na histopatologia dos pré-estômagos verificaram desprendimento de parte do 


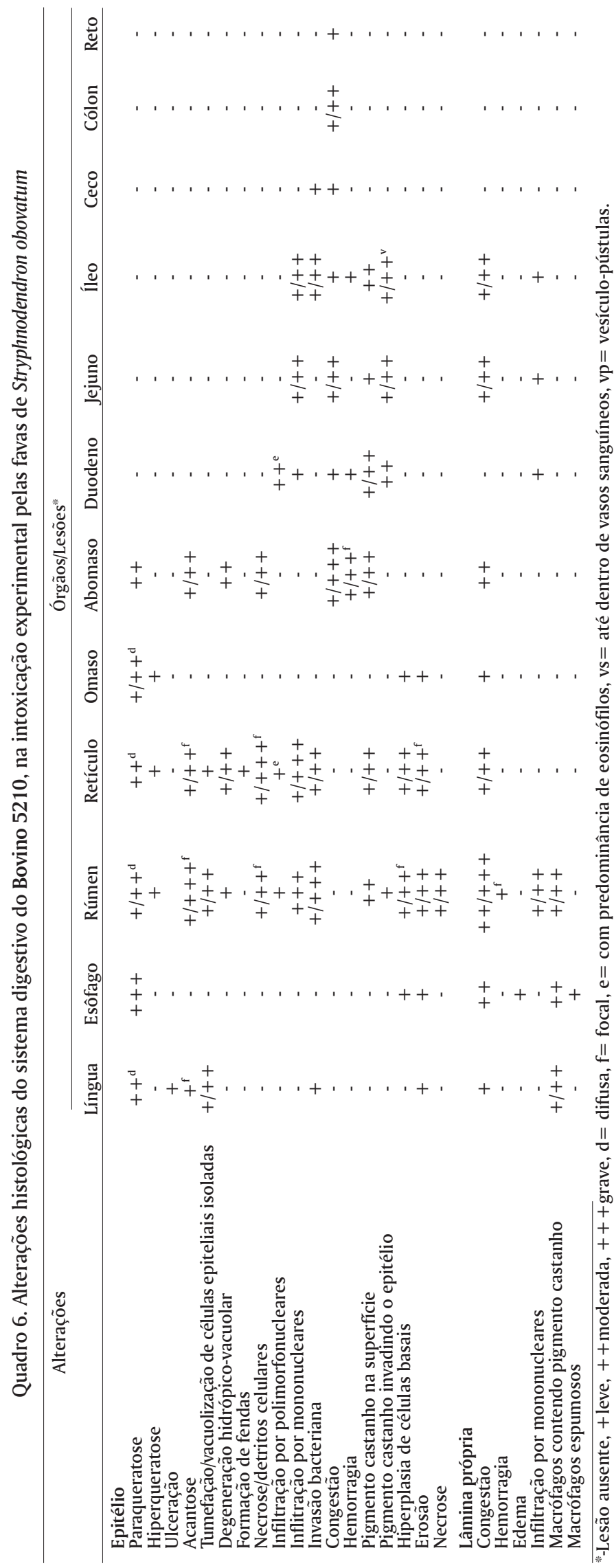

epitélio necrótico, com infiltrado polimorfonuclear e numerosas colônias bacterianas (Brito et al. 1995).

$\mathrm{Na}$ intoxicação experimental por Stryphnodendron barbatimao em bovinos, Pereira et al. (1989c) enfatiza as lesões regressivas no fígado e rim, mas não cita lesões nos pré-estômagos e atribui o quadro observado ao teor de tanino $(12 \%)$ contido nas favas. Relatam a presença de erosões nos lábios superiores e gengivas, mucosas pálidas ou hiperêmicas, petéquias e sufusões na mucosa do abomaso, enterite catarral e hemorrágica, tiflite hemorrágica, cólon com paredes espessadas e conteúdo achocolatado e edema do mesentério. Ao exame microscópico não observaram alterações no rúmen; no abomaso e intestino observaram severo edema da submucosa. Ainda no intestino, encontraram dilatação dos linfáticos, atrofia das vilosidades intestinais e enterite catarral subaguda. Macrófagos carregados de pigmento amarelado foram encontrados no baço e linfonodos.

Camargo (1965) porém, necropsiou quatro bovinos dos casos de intoxicação espontânea por S. obovatum e observou principalmente icterícia, hiperemia do rúmen e presença de sementes de $S$. obovatum no conteúdo; não faz referências às lesões do abomaso. Não realizou estudo histopatológico do trato gastrintestinal.

Kingsbury (1964) afirma que as saponinas contidas em algumas espécies de plantas podem causar desde irritação até uma severa gastrenterite na parede do trato digestivo. Tursch et al. (1963) isolaram saponinas das favas de S. coriaceum. $O$ princípio tóxico das favas de $S$. obovatum ainda não foi identificado, porém Brito et al. (2001) sugerem que talvez as saponinas sejam responsáveis ou pelo menos participem do quadro digestivo verificado nas intoxicações por $S$. obovatum em bovinos, $S$. coriaceum em bovinos e caprinos e $S$. barbatimao em bovinos.

As lesões macro e microscópicas dos pré-estômagos são compatíveis com o quadro de acidose ruminal grave, como o observado na intoxicação por S. obovatum em bovinos (Brito et al. 2001); as lesões do abomaso e dos intestinos, entretanto, sugerem que $S$. obovatum tem ação irritativa sobre o trato digestivo, corroborando com as observações clínicas destes autores.

Outras plantas de interesse pecuário são citadas na literatura como causa de alterações digestivas. A intoxicação por Baccharis coridifolia em bovinos (Tokarnia \& Döbereiner 1975, 1976, Varaschin et al. 1998), B. megapotamica var. megapotamica e var. weirii em bovinos (Tokarnia et al. 1992) e a intoxicação por B. megapotamica var. weirii em caprinos (Barbosa et al. 1994) e em ovinos (Armién et al. 1993) apresentam congruência de sinais clínico-patológicos com a intoxicação por S. obovatum. Em geral, na intoxicação por Baccharis spp em bovinos, além das perturbações digestivas, a necrose do sistema linfo-hematopoético e a necrose de hepatócitos, especialmente no que se refere a $B$. megapotamica var. megapotamica e var. weirii, são mais acentuadas do que na intoxicação por $S$. obovatum. Em função da necrose do sistema linfo-hematopoético, $B$. megapotamica var. weirii foi relatada como planta de ação radiomimética (Barbosa et al. 1994). 


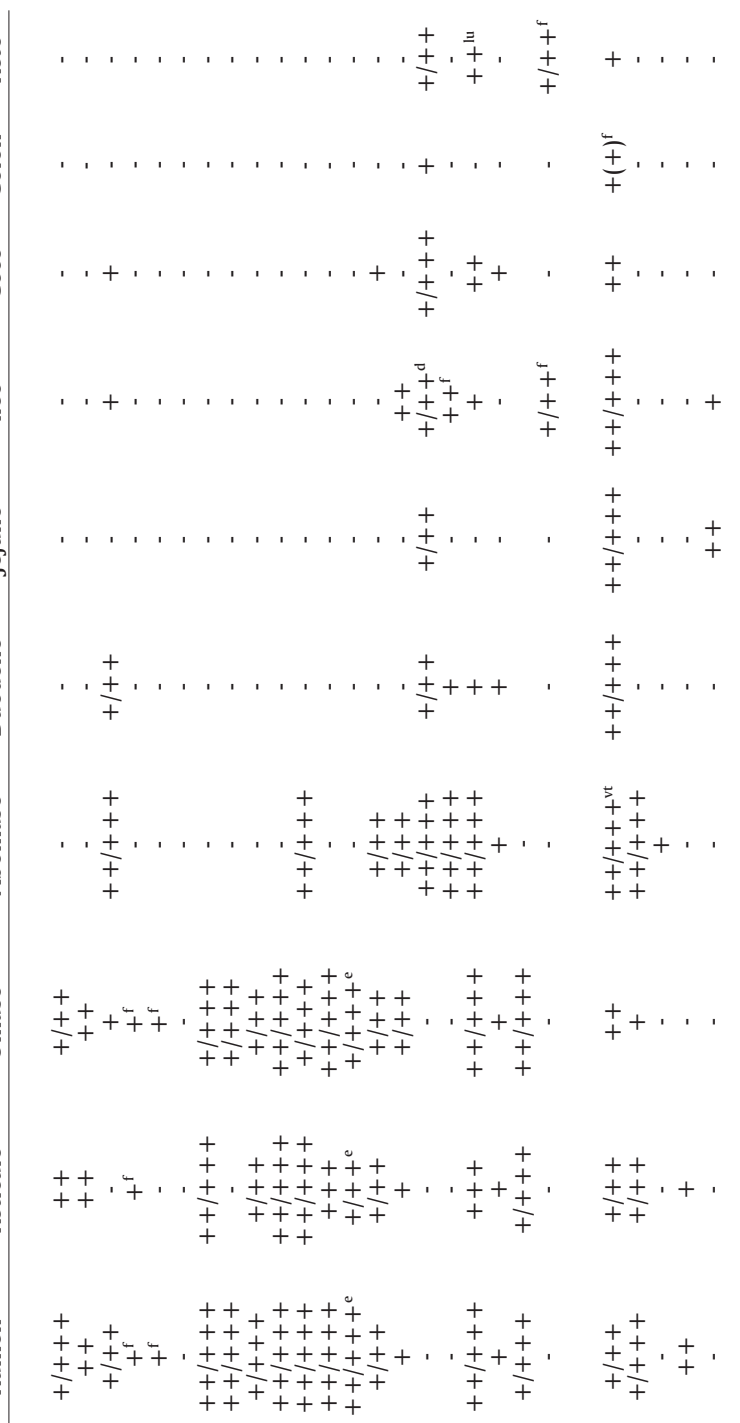

$+, \ldots,++, \ldots, \ldots, \ldots, 1, \ldots, \ldots$

$+$

$+$

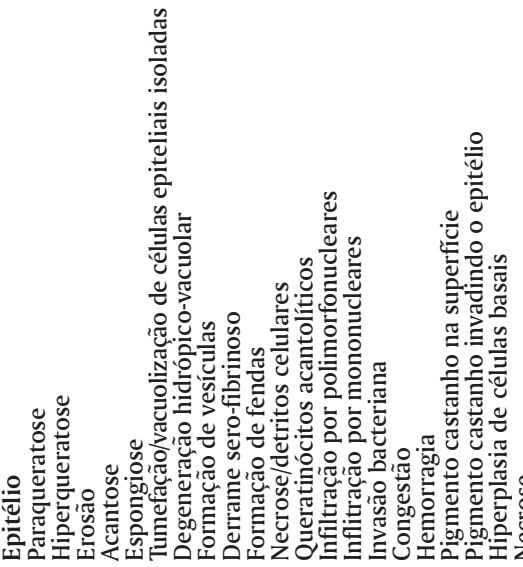

Ricinus comunnis provoca nos bovinos e em várias outras espécies animais, uma severa gastrenterite hemorrágica (Tokarnia \& Döbereiner 1997). As lesões encontradas por esses autores em bovinos e por Armién et al. (1996) em ovinos foram mais acentuadas no abomaso e intestino do que nos pré-estômagos, como a que se apresenta na intoxicação por S. obovatum em bovinos.

\section{REFERÊNCIAS}

Armién A.G., Peixoto P.V. \& Tokarnia C.H. 1993. Intoxicação experimental por Baccharis megapotamica var. megapotamica e var. weirii (Compositae) em ovinos. Pesq. Vet. Bras. 13(1/2):5-20.

Armién A.G., D’Angelis F.H. \& Tokarnia C.H. 1996. Intoxicação experimental pelas sementes de Ricinus communis (Euphorbiaceae) em ovinos. Pesq. Vet. Bras. 16(4):99-106.

Barbosa J.D., Armién A.G. \& Tokarnia C.H. 1994. Intoxicação experimental por Baccharis megapotamica var. weirii (Compositae) em caprinos. Pesq. Vet. Bras. 14(1):5-13.

Brito M.F., Armién A.G. \& Tokarnia C.H. 1995. Intoxicação experimental pelas favas de Stryphnodendron coriaceum (Leg. Mimosoideae) em caprinos. Pesq. Vet. Bras. 15(4):111-116

Brito M.F., Tokarnia C.H., Peixoto P.V., Silva H.K. \& Nogeira M. 2001. Intoxicação experimental pelas favas de Stryphnodendron obovatum (Leg. Mimosoideae) em bovinos. 1. Caracterização do quadro clínico. Pesq. Vet. Bras. 21(1):9-17.

Camargo W. 1965. Intoxicação em bovinos por "barbatimão" (Stryphnodendron obovatum Benth.; fam. Leguminosae). Biológico, São Paulo, 31(1):7-11.

Döbereiner J. \& Canella C.F.C. 1956. Intoxicação de bovinos pela fava do "barbatimão" (Stryphnodendron coriaceum Bth.). Bolm Soc. Bras. Med. Vet. 24:49-68.

Kingsbury J.M. 1964. Poisonous Plants of the Unites States and Canada. Prentice-Hall, Englewood Cliffs, New Jersey, p.32-33.

Pereira C.A., Santos H.L. \& Pessoa S.M. 1989. Intoxicação experimental em bovinos pela fava do "barbatimão" (Stryphnodendron barbatimao Mart.). III. Dados laboratoriais. Arq. Bras. Med. Vet. Zootec. 41(5):415-432.

Tokarnia C.H. \& Döbereiner J. 1975. Intoxicação experimental em bovinos por "mio-mio", Baccharis coridifolia. Pesq. Agropec. Bras., Sér. Vet. 10:7997.

Tokarnia C.H. \& Döbereiner J. 1976. Intoxicação experimental em ovinos por “mio-mio", Baccharis coridifolia. Pesq. Agropec. Bras., Sér. Vet. 11:19-26.

Tokarnia C.H. \& Döbereiner J. 1997. Sobre a imunidade cruzada entre os princípios tóxicos de Abrus precatorius e Ricinus communis. Pesq. Vet. Bras. 17(1):25-35.

Tokarnia C.H., Peixoto P.V., Gava A. \& Döbereiner J. 1991. Intoxicação experimental pelas favas de Stryphnodendron coriaceum (Leg. Mimosoideae) em bovinos. Pesq. Vet. Bras. 11(1/2):25-29.

Tokarnia C.H., Peixoto P.V., Gava A. \& Barros C.S.L. 1992. Intoxicação experimental por Baccharis megapotamica var. megapotamica e var. weirii (Compositae) em bovinos. Pesq. Vet. Bras. 12(1/2):19-31.

Tokarnia C.H., Döbereiner J. \& Peixoto P.V. 2000. Plantas Tóxicas do Brasil. Editora Helianthus, Rio de Janeiro.

Tursch B., Tursch E., Harrison I.T., Da Silva G.B.C.T.C.B., Monteiro H.J., Gilbert B., Mors W.B. \& Djerassi C. 1963. Terpenoides. LIII. Demonstration of ring conformational changes in triterpenos of the $\beta$-amyrin class isolated from Stryphnodendron coriaceum. J. Org. Chemistry 28:2390-2394.

Varaschin M.S., Barros C.S.L. \& Jarvis B.B. 1998. Intoxicação experimental por Baccharis coridifolia (Compositae) em bovinos. Pesq. Vet. Bras. 18(2):6975 . 